\title{
Criminalizing Racism: How did Twitter react?
}

\author{
Abraham G. van der Vyver and Tatiana Mengsen
}

\begin{abstract}
Racism remains a major issue in South Africa, almost 24 years after apartheid ended. History was made in the country when a court jailed Vicky Momberg for three years, with one year suspended, for using a derogatory word against a black police officer 48 times. Momberg, a white estate agent, was convicted of four counts of crimen injuria after her racist rant was caught on video and went viral on social media. Her explanation that she was not in a normal state at the time, as she had just been the victim of a smash-and-grab robbery, was rejected by the court.

In a seminal definition Benedict [1], defined racism as "the dogma that one ethnic group is condemned by nature to congenital inferiority and another group is destined to congenital superiority". Bonilla-Silva [2] postulated that the definition stood the test of time. He also pointed out that "[too] many social analysts researching racism assume that the phenomenon is self-evident, and therefore either do not provide a definition or provide an elementary definition."

The researcher captured and analysed 6540 unique tweets that were captured with nCapture and nVivo software. The tweets were posted between 10 November 2017 and 28 February 2018 in order to ascertain that part of the public opinion on the case that was reflected on Twitter. The analysis focused on themes and opinions. The public opinion reflected on Twitter showed a lot of support of the sentence. Criminal liability, the suitability of the sentence, and possible extenuating circumstance featured in the discourse.
\end{abstract}

Keywords-Social Media, Racism, Twitter.

\section{INTRODUCTION}

Legal history was made on 28 March 2018 when a white female, Vicky Momberg became the first South African to be sent to jail for an act of racism. Pijoos [3] reported that "Momberg was sentenced to an effective two years in prison by the Randburg Magistrate's Court on Wednesday for her racist tirade in 2016." Although the sentence amounted to three years in prison, one year was suspended for 3 years on condition that she did not commit a similar crime during that period.

Pijoos [3] reported that Momberg "was found guilty on four counts of crimen injuria on November 3 in connection with her rant, which started when she lashed out at a black police officer who had helped her after an alleged smash-and-grab incident in Northriding, Johannesburg."

Perez-Pena [4] commented in the New York Times that "( $(t)$ he decision was met mostly with celebration on social media, in a majority-black country where profound inequality coexists with memories of an apartheid system that institutionalized racial separation and oppression."

Abraham Gert van der Vyver is a senior lecturer at Monash South Africa, in the Department of Information Technology.

Tatiana Mengsen is with the Faculty of Business, Engineering and Technology, at Monash South Africa.

\section{DefinING RACISM}

Before a definition of racism can be construed, it is necessary to first define "race." "Race," according to Cole [5] is a social construct that is past its sell-by date. He refers to the work of the evolutionary geneticist Richard Lewontin who in 1972 pointed out that 85 per cent of human genetic diversity occurred within rather than between populations, and only 6-10 per cent of diversity is associated with the broadly defined 'races' [5].

In a seminal definition Benedict [1] defined racism as "the dogma that one ethnic group is condemned by nature to congenital inferiority and another group is destined to congenital superiority". Bonilla-Silva [2], postulated that the definition stood the test of time. He also pointed out that " $[\mathrm{t}] \mathrm{oo}$ many social analysts researching racism assume that the phenomenon is self-evident, and therefore either do not provide a definition or provide an elementary definition."

According to Hoyt [6] racism as a concept is difficult to teach and learn. He stated that it is "heavily freighted with multiple and conflicting definitions" but that there is always an element of prejudice, which he defines as "preconceived opinion not based on fact or actual experience" [6].

Gillborn [7] emphasized that not all acts of racism are blatant and elaborated that "racism as 'endemic' means that it goes far beyond 'crude, obvious acts of race hatred' to include 'the subtler and hidden operations of power that have the effect of disadvantaging one or more minority ethnic groups'."

Racism, according to Van Dijk [8] "can survive, only when it is daily reproduced through multiple sources of exclusion, inferiorization, or marginalization. Such acts need to be sustained by an ideological system, and by a set of attitudes that legitimate difference and dominance." In the case of South Africa racism was firmly entrenched in the political system of apartheid that was later declared as a crime against humanity [9].

Society has over the years grown in its rejection of racism. "The concept of racism is also heavily negatively loaded, morally and politically. Thus, to claim that someone has expressed a racist opinion is to denounce them as immoral and unworthy" [10].

Balint [11] postulated that promoting racial tolerance doesn't seem to be the solution to racism since racial intolerance, "because of its intentionality, seems only to be a small part of racism."

The Prevention and Combating of Hate Crimes and Hate Speech Bill was introduced in the Parliament of South Africa at the start of 2018. An explan-atory summary of Bill was published in Government Gazette No. 41543 of 29 March 2018). It will, in all probability be promulgated into an Act of Parliament in the near future. In its present form the Bill makes 
provision for an array of criminal offences with regard to hate crimes and hate speech [12].

\section{THE SOCIAL MEDIA}

The first detectable social network was launched in 1997, called Six Degrees. This network enabled a user to create his/her own profile and a list of friends [13]. Since the turn of the century the social media has become the dominant force in cyberspace. Social media refers to "online technologies and practices to share content, opinions and information, promote discussion and build relationships. Social media services and tools involve a combination of technology, telecommunications and social interaction [14].

Bloodsworth [15] referred to the social media as "the court of public opinion. Bady [16] feels that there is no such thing as the Court of Public Opinion. He sees this phenomenon as "litigation by hashtag" where "the unwashed masses constitute a kind of parallel legal system in which "mob justice" is meted out by "villagers with torches." In the Court of Public Opinion, they believe, "the one-eyed man with the most Twitter followers is king," and all the checks and balances of law and order are suspended." Schneier [17] differs from him and declares Facebook and Twitter as battlegrounds where these reputational battles are fought. According to him "The court of public opinion is an alternative system of justice", a platform where attacks on reputation, revenge, public shaming form part of the tactics.

\section{MEthodology}

In this study the researchers did an analysis of messages that were posted on Twitter. Twitter is a micro-blogging network, which enables users to send and/or receive text-based online messages (tweets) of up to 280 characters, spaces included. Each user has a set of subscribers known as followers. They can also follow other subscribers. Twitter updates usually consist of personal information about the users' comments on the topic depicted in the hashtag and/or linkages to content such as images, videos and news reports Vujić \& Zhang [18].

The data set consists of 189 unique tweets that were posted on the \#VickyMomberg hashtag between 18 and 19 March 2018. The authors used the nCapture and nVivo software packages to conduct a stakeholder as well as a thematic analysis on the tweets.

The social media renders a vast amount of diverse data. Similar information would have been extremely difficult to obtain in such large quantities prior to the establishment of the social media since large public surveys are normally costly and time-consuming. Researchers and business decision-makers started to take an interest in these data as a way of helping them identify consumer trends and predict their behaviour [13].

\section{ANALYSIS}

The authors conducted a stakeholder as well as a thematic analysis on the tweets. The tweets contain anecdotal evidence. They are littered with grammatical and syntactical errors yet best ethical practice dictates that editing should be restricted to a minimum. The authors have thus stuck to this guideline.
Stakeholders are persons or groups with legitimate interests in procedural and/or substantive aspects of corporate activity [19]. Thematic analysis is a method for identifying, analysing, and reporting patterns (themes) within data. It minimally organises and explains the data set in (rich) detail, however, it also lends itself to interpretation of the various dimensions of the research topic [20]. The authors found that the Twitter discourse was driven by themes and not stakeholders. Citizen journalists contributed a wide array of themes. Citizen journalism is defined as "the process of members within the public playing an independent role in collecting, reporting and distributing, current and breaking news events [21]. The following themes featured in the discourse:

a) A legal precedent

The courts have set a huge precedent to those people who are found guilty of Racist behaviour and Apartheid style practices towards non whites

Personally I would of wished that this matter be referred to a higher court. Judgement would have set a precedence and ultimately make it common law. Oh well, lets wait for the next racist!

b) A lesson

\#VickiMomberg this is a big lesson for white racist people you call me names. I keep quiet I go straight to open a case boom racist in jail 3 years imprisonment yoh. if $i$ was white it is a good time to learn an African language to avoid being racist

c) A slugline

\section{KILLING RACISM FOREVER!}

d) Abuse

If white people are so smart why don't they get it. You use the "k-word" you're a racist you go to jail.

Lol let the $b^{* * * h}$ rot in jail.

e) Anger

Let her swallow her $\mathrm{K}$ word for a while until she feels what it's like to be racist.

f) Apartheid

White people will never understand the pain caused by apartheid as they were not oppressed.

g) Apologists

Unfortunately, I foresee a few more \#VickiMomberg's in our future, as apologists and sympathisers come out of their cracks. More worrying, though, is those who crawl deeper into those cracks.

\section{h) Appeal}

Convicted racist \#VickiMomberg has lost her bid for leave to appeal her jail sentence.

Seems very convenient: \#VickiMomberg got convicted for a crime that can ONLY be perpetrated against BLACK South Africans. We're not "equal before the law". Magistrate Pravina Rugoonandan's not allowing of an appeal is Shaky. How did the video end up on youtube!?

If \#VickiMomberg left appeals and served time she'd be back by October...

No appeal for \#VickiMomberg, huh?

That's judicially groundbreaking alright, I'm assuming

i) Condemnation

Serves her right. 
j) Criticism

RT @Goldfingerza: Justice in South Africa becoming about as credible as the Salem Witch trials!

k) Crime

Racism serious crime in South Africa now.

1) Education

No, we should teach our kids not to use such words and that if they do they will be jailed like \#VickiMomberg. Our kids don't steal because we teach them the consequences thereof. Now think about it, will kids use these words knowing that this is the consequence? \#Stopracism

m) Equality

Seems very convenient: \#VickiMomberg got convicted for a crime that can ONLY be perpetrated against BLACK South Africans. We're not "equal before the law". Magistrate Pravina Rugoonandan's not allowing of an appeal is Shaky. How did the video end up on youtube!?

For once whites know how it feels to be black. When justice system dont work on your favour.

n) Extenuating circumstances

No point in contesting this really. It was a political statement, end of. In a first world society her case would have taken her trauma and mental health issues into account.

o) Fashion

@eNCA @Bongani20994708 She [Momberg] must get box braids next time...

So Vicky is wearing a black and white outfit.

p) Forgiveness

That's what am saying.. We forgave... we moved on.. All we asked was not to say the "k" word or be racist.

q) Hate speech

White people are out here outraged that \#vickiMomberg is arrested for being racist, a classic case of hate speech confused for free speech.

r) Incarceration

Let \#VickiMomberg be put in the same cell with black inmates so that she can learn to live with black people.

s) Jest

You know \#VickiMomberg could have avoided using the $\mathrm{K}$ word had she been fluent in an African language. She couldv called them sooo many other kool swear words n stay outta prison

Unlike other prisoners, \#VickiMomberg must get BLACK overalls.

t) Joy

What a time to be alive in Azania. These racist are being served left, right and center.

u) Justice

VickiMomberg Justice will always feel like oppression to the oppressors.

Justice was served to this proud racist women \#VickiMomberg. Let her be an example to her fellow racists.

Even those judges are driven subjectively, Objectivity is a myth: there is always a social, cultural or political perspective. People are driven by their beliefs and coming to decisions these perspectives are always involved.
Courts are the only thing working lately...\#BrianMolefe sorted yesterday, \#VickiMomberg today...next..let's keep it moving!

v) Logic

She was a victim of crime we get that, did people who tried to help her deserve to be insulted? No. Does she deserve to go to jail? Absolutely yes. We don't need racist here in our country.

w) Outcome

This outcome, like many, I understand.Tirades - by any one against any other person/group shoudn't be tolerated. I have \#NoSympathy for \#VickiMomberg.

The pendulum should swing both ways. Does it?

x) Plea (part of legal process)

She even pleaded not guilty after disrespecting us like that. She has to serve the full sentence.

\section{y) Query}

That's all good and all ... but what about all the rapists and woman abusers that are walking free?

\section{z) Racism}

Racism is bad white or black. The result of racial extremism is always violence. You can not have a rainbow nation if some find themselves superior. The tension between races is mostly about resources. The more we become unequal the more we shall disagree

No white person has the right to call black people racist. aa) Remorse

\#VickiMomberg is/was sorry and remorseful for her racist utterances,she'd agree to serve her sentence,without appealing for bail. She's a convicted criminal.

\section{bb) Scientific}

"In line with a position substantially argued by Cress-Welsing in The Isis (Ysis) Papers: The white supremacy system was inspired by a deep rooted inferiority complex and the resulting paranoia from the Caucasian collective."

"..the \#VickiMomberg racial slur is a fundamental part of white people's self defense, which when coupled with the systematic onslaught, proves perpetually devastating to the native collective.", argues Liza Mfana

@Kjbanks@P_JayMasterEC Dictionary defines racism as "prejudice or discrimination directed at someone of a different race based on the belief that one's own race is superior." Blacks don't believe their race is superior than others, whites do. Therefore blacks cannot be racist. Sit down! \#VickiMomberg. cc) Sentence

@ZolaNdwandwe u must be out of ur mind to suggest that \#VickiMomberg sentence is harsh.

\#VickiMomberg the judge was very lenient on this matter, what Vicki said was utterly disrespect on the peace of the nation and this has started to drag on because everything and what its being said to us keeps pilling more and more and she just added more hate to the nation.

dd) Standards

Absolutely disgusting that \#VickiMomberg has been refused leave to appeal she must go to the Constitutional Court yet Zuma Malema \& the whole bloody lot can. Not one black has been convicted of racism towards a white person. Our system has double standards. ee) Surpirse 
Never thought I would live to hear the phrase "convicted racist".

$$
\text { ff) Vow }
$$

One racist at a time. We coming after all of them. Those behind the door racists, those around the braai racist, those 'I have a black friend' racist we coming after you. 23 years on we can't be preaching the same thing over and over again.

\section{Media}

$$
\text { gg) Stakeholders }
$$

The various media outlets that reported on the conviction formed the most prominent stakeholder. In contrast to the contribution of many the citizen journalists whose tweets were emotionally-charged, the conventional media stuck to factual reporting. A number of examples are listed.

\section{2 (Radio)}

The court ruled that there are no prospects of success on the appeal.

\section{Capricorn News (local media)}

State prosecutor Yusuf Baba read evidence that was provided during the trial to the court which he said were not grounds for the defence to apply for leave to appeal the sentence and conviction.

\section{Qatar News (International)}

South African woman jailed for racist rant loses appeal bid. The Star (daily newspaper)

In case you missed it: \#VickiMomberg refused leave to appeal sentence and conviction.

\section{CONCLUSION}

The public opinion reflected on Twitter showed a lot of support for the conviction and the sentence. Criminal liability, the suitability of the sentence, and possible extenuating circumstance featured in the discourse. Whilst media reporting was restricted to factual reports that dealt with the uniqueness of the conviction as well as the sentence, the citizen journalists engaged in an emotive debate on the topic of racism. Many of the contributions contained racial slurs and/or embedded racism. Despite the relatively limited participation by the Twitterati the case study provided another example of how the social media offers a platform for the public to air their views on a political or polemical issue.

\section{REFERENCES}

[1] Benedict, R.F. (1945). Race and Racism. London: Routledge and Kegan Paul.

[2] Bonilla-Silva, E. (1997). Rethinking Racism: Toward a Structural Interpretation. American Sociological Review, Vol. 62, No. 3 (Jun., 1997), pp. 465-480. https://doi.org/10.2307/2657316

[3] Pijoos, I.(2018). Vicki Momberg sentenced to an effective 2 years in prison for racist rant. News24, 28 March, 2018 https://www.news24.com/SouthAfrica/News/vicki-momberg-sen tenced-to-an-effective-2-years-in-prison-for-racist-rant-2018032 8

[4] Perez-Pena, R. (2018). White Woman Is First South African Jailed for Racist Speech. New York Times(Foreign Desk), 29 March, 2018.

[5] Cole, R. (2016). Racism. London: Pluto Press.

[6] Hoyt, C. (Jr.). (2012). The pedagogy of the meaning of racism: reconciling a discordant discourse. Social Work, 27(3), 225-234. https://doi.org/10.1093/sw/sws009

[7] Gillborn, D. (2006) 'Critical race theory and education: racism and anti-racism in educational theory and praxis,' Discourse, 27(1), 20.

[8] Van Dijk, T. (2002). Denying Racism: Elite Discourse and Racism. In P. Essed\& D. T. Goldberg (Eds.), Race Critical Theories (pp. 307-324). Massachusetts:Blackwell.

[9] United Nations. (1973). International Convention on the Suppression and Punishment of the Crime of Apartheid. N.Y.: United Nations.

[10] Miles, R. \& Brown, M. (2003). Racism. Basingstoke: Palgrave Macmillan.

[11] Balint, P. (2016). The importance of racial tolerance for anti-racism. Ethnic and racial studies, 39(1), 16-32 http://dx.doi.org/10.1080/01419870.2016.1099713

[12] SA Parliament. (2018). The Prevention and Combating of Hate Crimes and Hate Speech Bill. Government Gazette No. 41543, 29 March 2018. Cape Town: Government Printer.

[13] Maresova, B., B. Klimova, and V. Tuček. 2015. "Use of Social Networks in Banking: A Study in the Czech Republic." Applied Economics 47 (57): 6155-6169. https://doi.org/10.1080/00036846.2015.1064083

[14] International Telecommunication Union, Smart Regulation in a Broadband World. $12^{\text {th }}$ Edition of Trends in Telecommunication Reform. (2012 May). Retrieved from http://www.itu.int/ITU-D/treg/publications/trends12.html

[15] Bloodsworth, D. On Trial in the Court of Public Opinion. Public Relations Strategist. Vol. 18 (2), 6-7.

[16] Bady, A. (2014) .There is no such thing as the Court of Public Opinion (but maybe there should be). The New Inquiry. Retrieved from http://thenewinquiry.com/blogs/zunguzungu/

[17] Schneier, B. (2013). The Court of Public Opinion is about mob justice and reputation as revenge. Wired, 26 Feb. 2013, retrieved from http://www.wired.com/2013/02/court-of-public-opinion/

[18] Vujić, S. \& Zhang, X. (2018) Does Twitter chatter matter? Online reviews and box office revenues. Applied Economics, 50:34-35, 3702-3717, DOI: 10.1080/00036846.201 8.1436148

[19] Donaldson, T. \& Preston, L.E. (1995), The Stakeholder Theory of The Corporation: Concepts, Evidence, and Implications. Academy of Management Review, Vol. 20(1), pp. 65-91. https://doi.org/10.2307/258887

[20] Boyatzis, R.E. (1998). 'Transforming qualitative information: Thematic analysis and code development', Sage, Thousand Oaks.

[21] Harvard Kennedy School (2016) Journalism Ethics in the Digital Age: A Model/Open Source Syllabus [online] http://journalistsresource.org/syllabi/ journalism-ethics-digital-age-syllabus\#sthash.2Lbcm0xr.dpuf (accessed 14 January 2016).

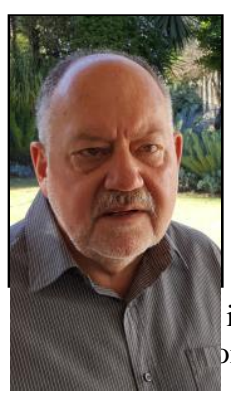
Abraham Gert van der Vyver is a senior lecturer at Monash South Africa. He has obtained degrees in law, marketing, communication, and information systems and the other authors may include biographies at the end of regular paper. His $\mathrm{PhD}$ is in political communications. He has also obtained an Australian Higher Education Diploma.

interest and research are social informatics, rmatics, cyberlaw, and ethics. 
Tatiana Mengsen is a Tanzanian that is part of the Faculty of Business, Engineering and Technology, at Monash South Africa. She has obtained a degree and post graduate in International Studies, Management and Criminology.

Her field of interest include Women and Children, Intercultural competences and mindfulness. 